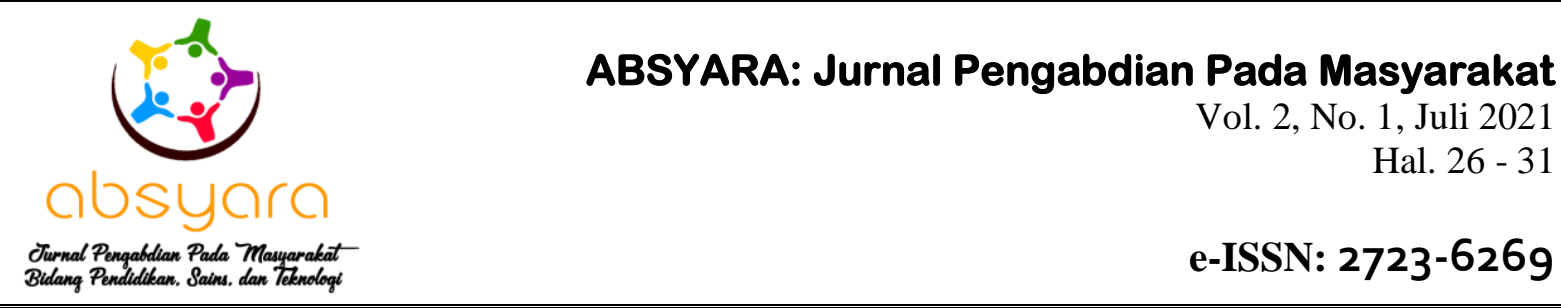

\title{
Pelatihan Online Internet Sehat sebagai Media Pembelajaran Bagi Siswa-Siswi SMK Nurul Huda Pemulutan Barat
}

\author{
Rasmila*1, Rahayu Amalia $^{2}$, Jemakmun $^{3}$, Aan Restu Mukti ${ }^{4}$ \\ rasmila@binadarma.ac.id ${ }^{* 1}$ \\ 1,3,4Program studi Teknik Informatika, Fakultas Ilmu Komputer, Universitas Bina Darma \\ ${ }^{2}$ Program studi Sistem Informasi, Fakultas Ilmu Komputer, Universitas Bina Darma
}

\begin{abstract}
Received: 1 Mei 2021
Accepted: 23 Juni 2021 Online Published: 31 Juli 2021

DOI: 10.29408/ab.v2i1.3403

URL: http://dx.doi.org/10.29408/ab.v2i1.3403
\end{abstract}

\begin{abstract}
Abstrak: Internet atau inter conection di era digital pada saat ini sangat erat kaitaanya dalam kehidupan seharihari dari kalangan anak-anak hingga kalangan dewasa, yaitu sebagai media bantu dalam mengerjakan dan menghubungkan berbagai aktivitas manusia secara efektif, akurat dan efisien. Internet juga merupakan suatu jaringan komunikasi yang memiliki fungsi untuk menghubungkan antara satu media elektonik dengan media elektronik lainnya dengan cepat dan tepat. Apalagi pada saat ini kita lagi dilanda pandemic COVID 19, pembelajaran online merupakan peraturan yang dikeluarkan oleh Pemerintah sebagai langkah pencegahan virus COVID 19. Efektivitas pembelajaran online dapat dipengaruhi oleh kualitas media pembelajaran online, maka dalam aktivitas pembelajaran menggunakan via online dan tak luput dari internet. Adapun peserta pelatihan online internet sehat adalah siswa-siswi SMK Nurul Huda Pemulutan Barat sebanyak 20 siswa - siswi. Tujuannya dari pelatihan ini agar siswa-siswi SMK Nurul Huda Pemulutan Barat dapat menggunakan internet sehat dalam media pembelajaran sehari-hari. Pelatihan dilaksanakan dengan cara interaktif menggunakan aplikasi ZOOM. Adapun harapan tercapai, siswa-siswi SMK Nurul Huda Pemulutan Barat memiliki pengetahuan dalam menggunakan internet sehat sebagai media pembelajaran.
\end{abstract}

Kata Kunci: Covid 19; Internet Sehat; Zoom

\begin{abstract}
Internet or interconnection in the digital era is closely related to everyday life from children to adults as an assistive medium in carrying out and connecting various human activities effectively, accurately, and efficiently. The internet is also a communication network that connects one electronic media with other electronic media quickly and precisely. Moreover, at this time, we are currently hit by the COVID 19 pandemic. Online learning is a regulation issued by the Government as a preventive measure against COVID 19, and the quality of online learning media can influence its effectiveness. This community service aims to educate 20's students of SMK Nurul Huda Pemulutan Barat about the healthy internet as a learning medium in their daily lives. The result has shown that the students know about Healthy Internet.
\end{abstract}

Keyword: Covid 19; Healthy Internet; Zoom 


\section{PENDAHULUAN}

Sudah lebih dari satu tahun pandemi Covid-19 berlangsung di Indonesia, hal ini mempengaruhi seluruh bidang termasuk bidang pendidikan. Saat ini pembelajaran dilakukan dengan sistem daring yang memanfaatkan teknologi informasi (TI) sebagai media pembantu (Fauzi, dkk., 2020). TI tidak terlepas dari kehidupan masyarakat Indonesia sehari-hari, dari kalangan anak-anak sampai orang tua, sehingga pemanfaatan TI sudah menjadi bagian dari gaya hidup masyarakat (Herlinda \& Prasetya, 2018). Penggunaan TI seperti dua mata pisau, artinya memiliki dampak negatif dan dampak positif, tergantung bagaimana kita menggunakannya (Sholeh \& Basuki, 2018). Pada masa pandemi Covid-19 ini, TI yang paling dibutuhkan dalam proses pembelajaran bidang pendidikan adalah internet. Teknologi internet sudah menjadi salah satu kebutuhan yang sangat diperlukan dalam kehiudpan sehari-hari. Hal ini dibuktan melalu data survey yang dirilis oleh Asosiasi Penyelenggara Jasa Internet (APJII) bahwa jumlah penetrasi pengguna internet di Indonesia pada tahun 2019-2020 (Q2) mencapai 197,7 juta pengguna dengan presentase sebesar 73,3\% dari 266,9 juta jumlah penduduk Indonesia (APJII, 2020). Besarnya pengguna internet di Indonesia tidak terlepas dari dampak negatif penggunaan internet, terutama dikalangan remaja yang akan menjadi generasi penerus bangsa. Kesuksesan bangsa Indonesia terletak pada bagaimana kualitas sumber daya manusianya (Arianti, dkk., 2020). Remaja sebagai generasi penerus bangsa merupakan sumber daya manusia yang harus dibentengi dari berbagaimacam dampak negatif dari penggunaan internet.

Guna mengedukasi masyarakat mengenai dampak penggunaan internet terutama dikalangan remaja, maka perlu diadakan edukasi-edukasi mengenai dampak penggunaan internet terutama di kalangan remaja. Oleh karena itu kegiatan pengabdian ini dilakukan untuk mengedukasi siswa SMK Nurul Huda Pemulung Barat dalam memanfaatkan teknologi internet secara positif dengan memanfaatkan internet sebagai media pembelajaran, sehingga para siswa dapat menggunakan internet dengan lebih bijak dan optimal. Pengabdian ini mengambil siswa sebagai peserta karena mengingat persentase pengguna internet dikalangan remaja cukup besar, yaitu sekitar 16,68\% (Guntoro, dkk., 2019).

\section{METODE PELAKSANAAN}

\section{Waktu dan Lokasi}

Pelaksanaan pelatihan ini dilakukan untuk SMK Nurul Huda Pemulutan Barat selama 2 hari pada bulan September 2020 dan dilaksanakan secara online / daring menggunakan Live Zoom Meeting.

\section{Prosedur pelaksanaan}

Adapun tahapan pelaksanaan kegiatan pelatihan pengabdian pada siswa - siswi SMK Nurul Huda Pemulutan Barat menggunakan metode Action Research (Rasmila \& Amalia, 2019), dimana pada metode ini segala kondisi yang terjadi dijelaskan bersamaan dengan tujuan untuk memperbaiki serta mengembangkan kondisi yang terjadi saat ini (Dasmen, 2018). Berikut ini merupakan gambar diagram dari metode action research (Chandra \& Amalia, 2019) : 


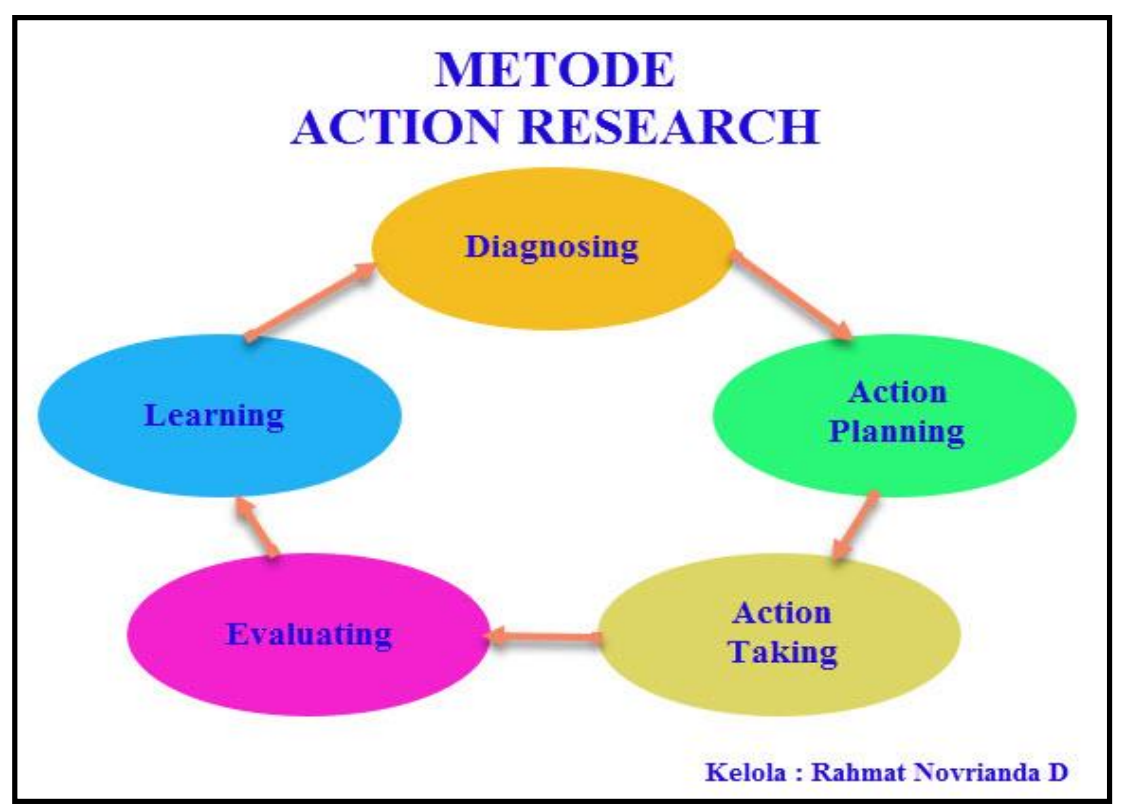

Gambar 1. Metode Action Research (Dasmen \& Rasmila, 2019)

1) Diagnosing

Tim melakukan penyebaran kuesioner kepada Peserta Pelatihan sebelum kegiatan PKM dimulai. Dari hasil kuesioner yang diberikan berkaitan dengan Pemahaman tentang internet sehat, diperoleh $40 \%$ dari Peserta yang dapat dikatakan mengetahui tentang internet sehat.

2) Action Planning

Dari hasil analisis yang dilakukan sebelumnya, maka dipersiapkan materi berkaitan dengan teori internet sehat serta pemanfaatannya. Dalam PKM ini diutamakan pemanfaatan internet sehat dalam proses pembelajaran sebagai media ajar. Selain itu, Tim PKM juga mempersiapkan media Live Zoom Meeting untuk dapat melakukan Pelatihan serta Penyampaian materi secara daring kepada siswa-siswi SMK Nurul Huda Pemulutan Barat.

3) Action Taking

Setelah melakukan perencanaan, Tim PKM menyebarkan link Live Zoom Meeting kepada SMK Nurul Huda Pemulutan Barat khususnya untuk siswa-siswi SMK Nurul Huda Pemulutan Barat. Setelah itu, diadakan Pelatihan secara daring menggunakan Live Zoom Meeting untuk menyampaikan materi tentang teori internet sehat serta pemanfaatan internet sehat dalam proses pembelajaran SMK Nurul Huda Pemulutan Barat

4) Evaluation

Setelah kegiatan Pelatihan dilaksanakan, maka Tim PKM menyebarkan kuesioner lagi kepada Peserta Pelatihan dengan butir pertanyaan yang sama dengan kuesioner pada saat sebelum Pelatihan dilaksanakan. Adapun hal ini dilakukan untuk mengevaluasi perbandingan hasil sebelum dan setelah Pelatihan dilaksanakan terhadap siswa-siswi SMK Nurul Huda Pemulutan Barat. Dari hasil kuesioner yang disebarkan, diperoleh 75\% Peserta Pelatihan telah mengetahui tentang internet sehat. 


\section{5) Learning}

Pada tahapan ini, Tim melakukan pembelajaran dari hasil evaluasi yang diperoleh, dimana yang dimaksud dengan "Mengetahui tentang internet sehat" adalah Peserta yang dapat menjawab dengan benar 20-25 pertanyaan dari 25 pertanyaan kuesioner yang diberikan. Dari hasil 75\% Peserta yang mengetahui tentang internet sehat, dapat dipelajari lagi bahwa Peserta yang benar-benar memahami tentang internet sehat akan dapat menerapkan ataupun memanfaatkan internet sehat dalam proses pembelajaran SMK Nurul Huda Pemulutan Barat

\section{HASIL DAN PEMBAHASAN HASIL}

Kegiatan pelatihan online tentang internet sehat sebagai media pembelajaran dilaksanakan pada hari Jumat dan Sabtu / 11-12 September 2020. Tujuan kegiatan ini adalah untuk meningkatkan pengetahuan siswa - siswi SMK Nurul Huda Pemulutan Barat tentang desain internet sehat sebagai media pembeljaran daring pada masa pandemi covid-19 saat ini.

Berikut ini beberapa dokumentasi saat pelaksanaan Pelatihan Online tentang internet sehat terhadap Siswa - Siswi SMK Nurul Huda Pemulutan Barat :

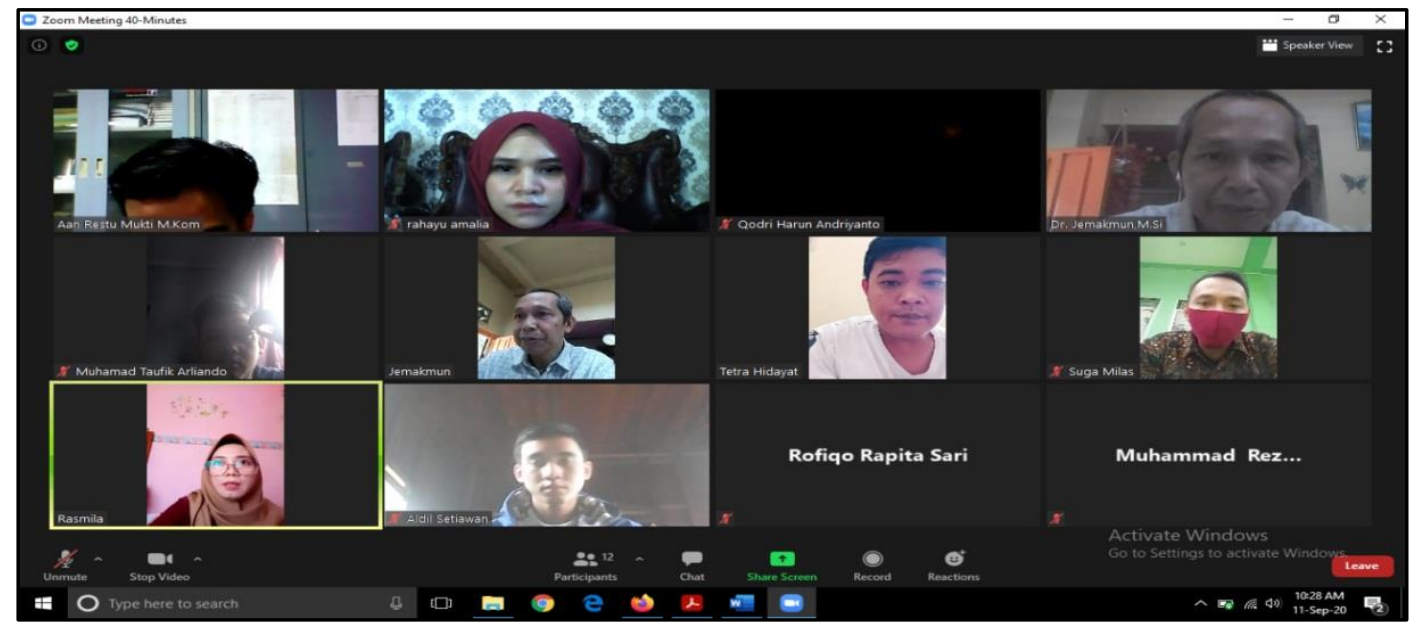

Gambar 2. Proses Pembukaan Pelatihan secara online

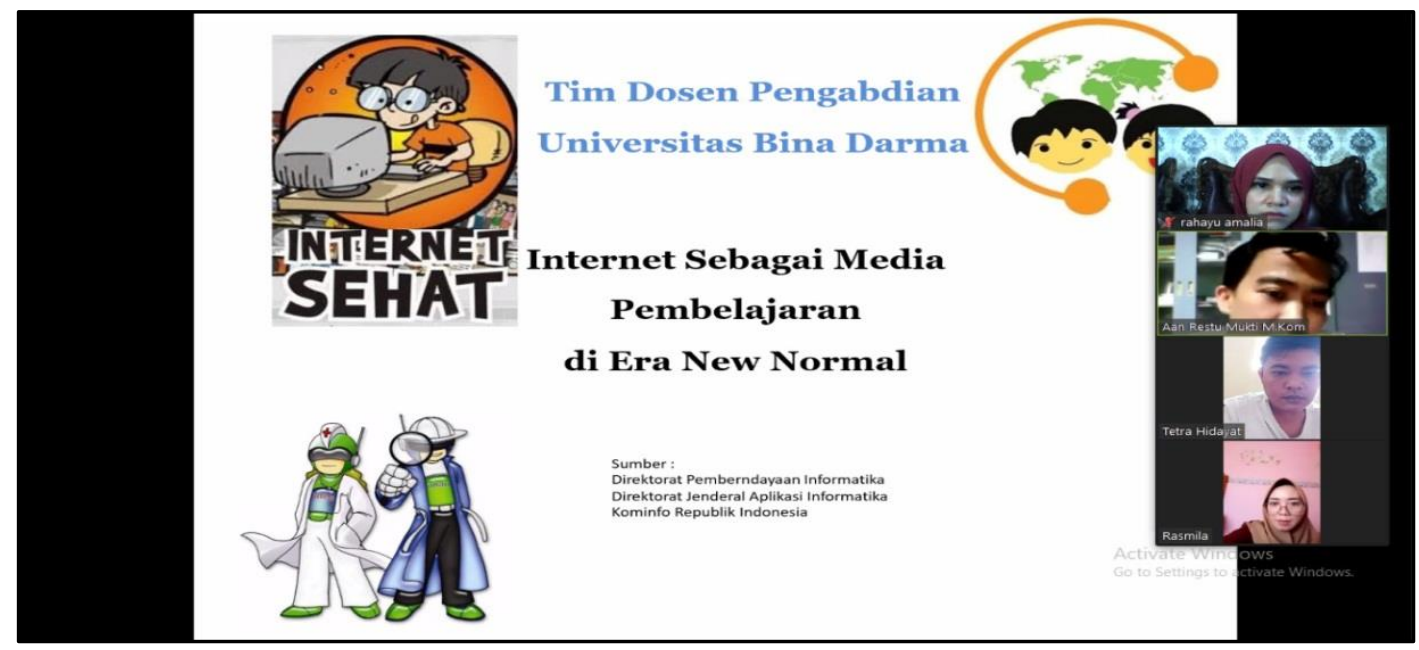

Gambar 3. Pemaparan Materi 1 


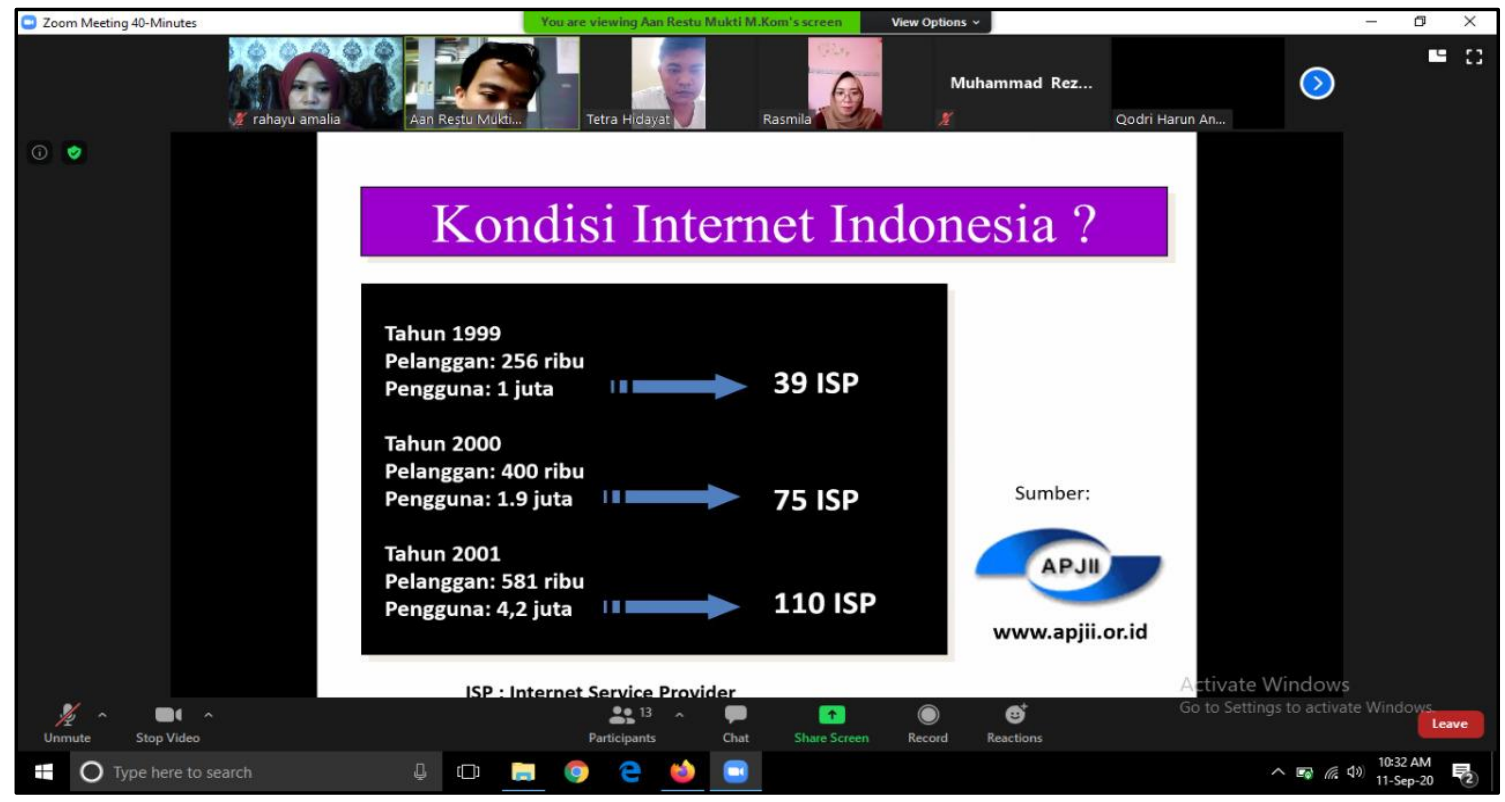

Gambar 4. Pemaparan Materi 2

\section{PEMBAHASAN}

Dari kegiatan pelatihan yang dilaksanakan, diberikan pemaparan materi terkait dengan internet sehat dan fokusnya sebagai media pembelajaran, kemudian terjadi diskusi interaktif terhadap Siswa - Siswi SMK Nurul Huda Pemulutan Barat. Oleh karena itu, dapat dilihat terjadi pertambahan ataupun perkembangan pengetahuan peserta pelatihan. Hal ini dapat dilihat dari hasil kuesioner yang disebarkan, sebelum pelatihan hanya $30 \%$ peserta yang mengetahui tentang internet sehat, kemudian terjadi kenaikan menjadi $75 \%$ peserta pelatihan mengetahui tentang internet sehat setelah pelatihan online dilaksanakan. Selain itu, Siswa - Siswi SMK Nurul Huda Pemulutan Barat yang memahami internet sehat juga dapat menerapkan ataupun memanfaatkan internet sehat sebagai media pembelajaran dengan bijak dan optimal. Hal ini sejalan dengan hasil pengabdian yang dilakukan oleh Guntoro (2019)

\section{SIMPULAN}

Hasil dari kegiatan pengabdian pada masyarakat pelatihan online tentang internet sehat sebagai media pembelajaran adalah siswa - siswi SMK Nurul Huda Pemulutan Barat diharapkan yang mengikuti pelatihan ini dapat mengembangkan keterampilan diri melalui internet. Dengan adanya pelatihan internet sehat ini harapannya siswa - siswi dapat terhindar dari bahayanya internet dari sisi negative dan siswa - siswi SMK Nurul Huda Pemulutan Barat dapat mengetahui tips dan cara berinternet sehat dan nyaman. Serta siswa - siswi SMK Nurul Huda Pemulutan Barat mendapatkan motivasi, ilmu dan wawasan tentang Teknologi Informasi dan cara menggunakan internet sehat dan aman

\section{PERNYATAAN PENULIS}

Artikel pengabdian kepada masyarakat berjudul "Pelatihan Online Internet Sehat sebagai Media Pembelajaran Bagi Siswa-siswi SMK Nurul Huda Pemulutan Barat" ini belum pernah dipublikasikan dalam jurnal ilmiah manapun. 
Rasmila, R., Amalia, R., Jemakmun, J., \& Mukti, A. R. (2021). Pelatihan online internet sehat sebagai media pembelajaran bagi siswa-siswi SMK Nurul Huda Pemulutan Barat. ABSYARA: Jurnal Pengabdian Pada Masyarakat, 2(1), 26-31. doi:10.29408/ab.v2i1.3403

\section{DAFTAR PUSTAKA}

APJII. (2020, November 9). Survei. Diambil kembali dari Asosiasi Penyelenggara Jasa Internet Indonesia: https://apjii.or.id/survei2019x

Arianti, B. D. D., Kholisho, Y. N., \& Sujatmiko, S. B. (2020, May). The development of elearning use MOODLE as a multimedia learning medium. In Journal of Physics: Conference Series (Vol. 1539, No. 1, p. 012033). IOP Publishing.

Chandra, W., \& Amalia, R. (2019). Sistem informasi pemesanan kamar mess PT. KAI Persero Divre III Sumatera Selatan. CESS (Journal of Computer Engineering, System and Science), 4(1), 88-93.

Dasmen, R. N. (2018). Implementasi Raspberry Pi 3 sebagai wireless access point pada STIPER Sriwigama Palembang. Jurnal Informatika, 3(03), 387-393.

Dasmen, R. N., Rasmila, R., (2019). Implementasi Raspberry Pi 3 pada sistem pengontrol lampu berbasis Raspbian Jessie.JEPIN (Jurnal Edukasi dan Penelitian Informatika), 5(1), 46-53.

Fauzi, L. M., Supiyati, S., \& Rasidi, A. (2020). Workshop Distance Learning di masa pandemic Covid 19. ABSYARA: Jurnal Pengabdian Pada Masyarakat, 1(1), 16-21.

Guntoro, G., Lisnawita, L., \& Sadar, M. (2019). Pelatihan internet sehat dan aman bagi siswa SMK Masmur Pekanbaru. Jurnal Pengabdian Pada Masyarakat, 4(2), 223-230.

Herlinda, H., \& Prasetya, R. (2018, September). Memantau anak dan smartphone untuk keamanan akses internet warga Pondok Labu-Jakarta. In Seminar Nasional dan Diskusi Panel Multidisiplin Hasil Penelitian dan Pengabdian Kepada Masyarakat 2018 (Vol. 1, No. 1).

Rasmila, R., \& Amalia, R. (2019). Sistem informasi penentuan persiapan stok obat menggunakan weighted moving average. Sistemasi: Jurnal Sistem Informasi, 8(3), 465-478.

Sholeh, M., \& Basuki, U. J. (2018). Pemahaman remaja Masjid Al Aman Kersen Bantul pada pengelolaan media sosial secara sehat dan cerdas. Jurnal Abdimas PHB: Jurnal Pengabdian Masyarakat Progresif Humanis Brainstorming, 1(2), 111-118. 